\title{
The Importance of Infrastructure Facilities in Counseling Services
}

\author{
Verlanda Yuca, Daharnis, Riska Ahmad, Zadrian Ardi \\ Universitas Negeri Padang, Padang, Indonesia
}

e-mail: reland@gmail.com

\begin{abstract}
The background of this research the lack of implementation of guidance and counseling services at Junior High School in Padang. The adequacies of infrastructure are factors suspected to affect the implementation of guidance and counseling services. This study described the correlation of the adequacy of infrastructure with the implementation of guidance and counseling at school. This study used a descriptive-correlation method. The study populations were guidance and counseling teacher of Junior High School in Padang, amount to 130 people. The samples were 55 people, who had chosen by random sampling technique. The instrument was a questionnaire with reliability test of the adequacy of infrastructure amounted to 0.910 , and the implementation of guidance and counseling services 0.912 . Data were analyzed with descriptive statistics and simple linear regression. The results are (1) the adequacy of guidance and counseling infrastructure at schools are in the category of sufficient, (2) the implementation of guidance and counseling services at schools are at high category, and (3) there is a correlation between the infrastructure with the implementation of guidance and counseling services $(\mathrm{r}=$ 0.426 , significance 0.001 ).
\end{abstract}

Keywords: Infrastructure, Implementation Service Guidance and Counseling

\section{INTRODUCTION}

Counseling is an integral part of education activities that are implemented in schools into counselor's responsibilities [1]-[4]. Counseling is a systematic, objective, logical, continuous and programmatic effort by counselors to develop the independence in student's lives [1], [4]. School is one of the educational institutions that require counseling services in the implementation and improvement of living conditions in schools for the achievement of educational goals that going along with the vision of the counseling profession [6][7]. In realizing a happy and optimally developing human life, independent, the counseling services can be implemented in the form of activities and assistance in individuals [4].

Counseling activities conducted in the context of direct ways to students in classical that need to be allocated 1-2 hours per class per week and outside activities is possible up to $50 \%$ of all activities counseling [9][10]. The goal of counseling in schools is to help individuals develop themselves optimally according to their own stages of student development in learning, social, personal, and career [11]-[16]. The types of services that can be implemented include orientation services, information services, placement and distribution services, content mastery services, individual counseling services, group counseling services, consultation services, mediation services and advocacy services [2], [4], [16]-[19].

In order for the implementation of counseling services can be implemented optimally, it is very necessary to cooperation between counselors with other school personnel. One of the cooperation that supports the implementation of counseling service in school is with the school principal [20][21]. The principal is responsible for the overall implementation of education in schools including the implementation of counseling services at school [13][22]. The role of school principals in achieving counseling goals in schools lies in the ability of school principals in performing their functions and duties, that are: 1) coordinate all activities programmed in schools, so that the teaching, training and counseling services is an integrated, harmonious, and dynamic, 2) providing infrastructure, resource, and various facilities for the implementation of effective and efficient counseling services, 3) supervising and guiding the planning and implementation of the program, assessment and undertaking counseling services, 4) accountability and counseling services at the school to the State 
Education Office to which he / she supervising; 5) facilitate counselor to develop their professional skills through professional development activities; and 6) provide facilities, opportunities and support in supervisory activities undertaken by supervisor of counseling [4], [8].

Counselor is the main implementer of counseling service at school [23]-[25]. The duties of counselor include: 1) implement counseling services, 2) promote counseling services, 3) planning program counseling services, 4) carry out the whole program counseling services, 5) evaluate the process and outcomes program implementation counseling services, 6) carry out follow-up based on the results of the evaluation of counseling services, 7) administration the activities of counseling services, 8) accountability for tasks and activities in counseling services to the coordinator of counseling [26][27][13]. Implementation of counseling services in schools can't be separated from the influence of infrastructure facilities that used by counselor [28][30]. Infrastructure in the school is the one of supporting factors in counseling service [31][32]. No matter how great the mastery of science and technology of counselor, without the support of adequate infrastructure facilities then the expected results can't be achieved maximally. The educational infrastructure is important because the quality of education can be enhanced through the provision of appropriate infrastructure standards already set [23], [33], [34].

This study aims is to describe the relationship between the adequacy of infrastructure with the implementation of counseling services.

\section{METHODS}

Data were collected using instruments with Likert Scale models. Instruments are also complemented by the identification of respondents' data through related to various aspects, such as gender, place of duty, education, status and duration of work, and more. The sample of the research is the counselor of SMP in Padang as many as 55 people. Data were analyzed with correlation-descriptive statistics [35]-[38].

\section{RESULT}

The results of this study indicate that there is correlation between the adequacy of infrastructure and the implementation of counseling services in schools [28]. A description of the adequacy of infrastructure and implementation of counseling services are shown in Table 1 and Figure 1.
Table 1 The Adequacy of Infrastructure Facilities and Counseling Service Implementation

\begin{tabular}{|l|c|c|c|c|}
\hline \multirow{2}{*}{ Criteria } & \multicolumn{2}{|c|}{$\begin{array}{c}\text { Adequacy of } \\
\text { Infrastructure } \\
\text { Facilities }\end{array}$} & \multicolumn{2}{c|}{$\begin{array}{c}\text { Service } \\
\text { Implementation } \\
\text { Counseling }\end{array}$} \\
\cline { 2 - 5 } & $\mathbf{f}$ & $\mathbf{\%}$ & $\mathbf{f}$ & $\mathbf{\%}$ \\
\hline High & 27 & 49 & 45 & 81,82 \\
\hline Medium & 28 & 51 & 10 & 18,18 \\
\hline Low & 0 & 0 & 0 & 0 \\
\hline Total & $\mathbf{5 5}$ & $\mathbf{1 0 0}$ & $\mathbf{5 5}$ & $\mathbf{1 0 0}$ \\
\hline
\end{tabular}

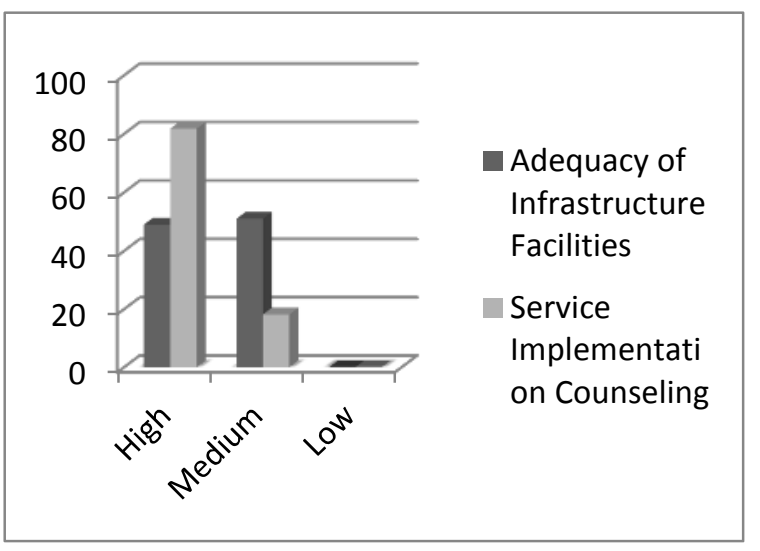

Figure 1. Level of Adequacy of Infrastructure Facilities and Service Implementation Counseling (\%)

When analyzed from the level of adequacy of infrastructure and implementation of counseling services (Table 1 and Graph 1), 49\% of respondents feel the level of adequacy of infrastructure facilities and implementation of counseling services in the category of moderate and $51 \%$ feel in the high category. At counseling service, $18.2 \%$ of respondents felt counseling service at school in medium category and $81.8 \%$ in high category. This can be one of the basic and considerations in the preparation of improvement in the implementation of counseling services with due attention to the condition of the adequacy of the infrastructure of counselor at school.

In terms of statistics obtained a moderate and significant correlation $(\mathrm{r}=0.426)$ between the adequacy of infrastructure facilities with the implementation of counseling services. This implies that the higher the level of the adequacy of the infrastructure in the school, the higher level of counseling service implementation by the counselor and so do the opposite [28], [29], [39].

High or low relationship between the adequacy of infrastructure and counseling services became one of the important considerations in making programs, quality improvement and service quality counseling 
in schools and cope the various problems that arise relating to counseling service. Considerations in program making, quality improvement and quantity of infrastructure for solutions to problems of nonimplementation of counseling services are one of the key factors for counselor. In improving the quality of these infrastructure facilities is not separated from the role of principals [40][41].

The results of this study could be evidence that the infrastructure is so important in the implementation of counseling services, which there is a correlation between the adequacies of infrastructure facilities with the implementation of counseling services. This implies that the higher the level of the adequacy of infrastructure in the school, the higher the level of counseling service implementation by counselor and vice versa.

One important factor in supporting the optimization of the implementation of counseling services in schools is the adequacy of infrastructure facilities. This condition is influenced by various factors, including the role of principal in sufficient infrastructure in the school so that Counselor can perform counseling services optimally. The phenomenon that emerges based on the exposure of the research results indicates that the adequacy level of infrastructure and the implementation of counseling service is low enough so that this affects the Counselor in optimizing the provision of counseling services at school. This condition demands an effort by the school principal to improve the quality of infrastructure and alleviate the inaccessibility of counseling services in schools.

\section{CONCLUSIONS}

Result of this research has been found that infrastructure facilities are so essential in the implementation of counseling services; the counselor can assess the completeness of infrastructure variously. This has an impact on the varied implementation of counseling service. Both aspects are also shown by the correlation between the completeness of infrastructure facilities with the implementation of counseling services in schools. Therefore, the management of education is expected to complete the infrastructure so that the implementation of counseling runs optimally; in addition to the improved management and cooperation between various parties are needed.

For further researchers it is desirable to conduct in-depth qualitative studies, especially on how counselors respond to lack of infrastructure and on more populations and samples.

\section{REFERENCES}

[1] D. Gibson, C. T. Dollarhide, and J. M. Moss, "Professional Identity Development: A Grounded Theory of Transformational Tasks of A Grounded Theory of Transformational Tasks of Counselors," J. Couns. Dev., no. January 2015, 2014.

[2] S. T. Gladding, Counseling: A comprehensive profession. Pearson Higher Ed, 2012.

[3] S. Hastuti and W. S. Winkel, "Bimbingan dan Konseling." Yogjakarta: Media Abadi, 2012.

[4] Kementerian Pendidikan dan Kebudayaan, Permendikbud Nomor 111 tahun 2014 tentang Bimbingan dan Konseling pada Pendidikan Dasar dan Pendidikan Menengah. 2014.

[5] B. P. O. Paisley and L. D. Borders, "School Counseling: An Evolving Specialty By Pamela O. Paisley, L. DiAnne Borders This is the prepeer reviewed version of the following article: Paisley, P. O., \& Borders, L. D. (1995). School counseling: An evolving specialty.," vol. 74, pp. 150-153, 1995.

[6] C. A. Dahir and C. B. Stone, "School counselor accountability: The path to social justice and systemic change," J. Couns. Dev., vol. 87, no. 1, pp. 12-20, 2009.

[7] P. Sahlberg, "Education policies for raising student learning: The Finnish approach," J. Educ. Policy, vol. 22, no. 2, pp. 147-171, 2007.

[8] E. Prayitno \& Amti, Pedoman Khusus Bimbingan dan Konseling. 2004.

[9] P. M. McDonough, "Counseling matters: Knowledge, assistance, and organizational commitment in college preparation," Prep. Coll. Nine Elem. Eff. outreach, pp. 69-87, 2005.

[10] C. for D. C. and Prevention, "Best practices for comprehensive tobacco control programs2007," Atlanta US Dep. Heal. Hum. Serv. Centers Dis. Control Prev. Natl. Cent. Chronic Dis. Prev. Heal. Promot. Off. Smok. Heal., p. 8, 2007.

[11] A. J. Nurihsan, "Strategi Layanan Bimbingan dan Konseling," Bandung: Refika Aditama, 2005.

[12] N. C. Gysbers, "School guidance and counseling in the 21st century: Remember the past into the future," Prof. Sch. Couns., vol. 5, 
no. 2, pp. 96-106, 2001.

[13] N. C. Gysbers and P. Henderson, Developing and managing your school guidance and counseling program. John Wiley \& Sons, 2014.

[14] Z. Ardi, "Cita-cita Perkerjaan dan Pilihan Peminatan Siswa Sekolah Menengah Atas Negeri di Sumatera Barat," Cita-cita Perkerjaan dan Pilihan Peminatan Siswa Sekol. Menengah Atas Negeri di Sumatera Barat, 2014.

[15] D. Daharnis and Z. Ardi, "THE COMPATIBILITY STUDENT CHOICE OF UNIVERSITY MAJORING; A PRELIMINARY STUDIES," Guid. J. Guid. Couns. Psychol. Educ., vol. 6, no. 1, pp. 101109, 2016.

[16] Daharnis, Erlamsyah, Ifdil, Z. Ardi, and R. Hariko, "Gambaran Kegiatan Belajar Siswa Sumatera Barat," in Seminar Internasional Bimbingan dan Konseling, 2014, vol. 1, no. 20, pp. 1-9.

[17] Prayitno, Pembelajaran melalui Pelayanan BK di Satuan Pendidikan. 2013.

[18] R. L. Gibson and M. H. Mitchell, "Introduction to guidance and counseling," 2003.

[19] Z. Ardi and F. M. Yendi, "Konseling Online: Sebuah Pendekatan Teknologi Dalam Pelayanan Konseling," J. Konseling dan Pendidik., vol. 1, no. 1, pp. 1-5, 2013.

[20] M. A. Clark and J. C. Breman, "School Counselor Inclusion: A Collaborative Model to Provide Academic and Social $\square$ Emotional Support in the Classroom Setting," J. Couns. Dev., vol. 87, no. 1, pp. 6-11, 2009.

[21] E. Amatea and M. Clark, "Changing schools, changing counselors: A qualitative study of school administrators' conceptions of the school counselor role," Prof. Sch. Couns., vol. 9, no. 1, pp. 16-27, 2005.

[22] S. F. Shaw and J. W. Madaus, "Preparing school personnel to implement section 504," Interv. Sch. Clin., vol. 43, no. 4, pp. 226-230, 2008.

[23] Presiden Republik Indonesia, Undang-undang No. 20 Tahun 2003 Tentang Sistem Pendidikan Nasional. 2003.

[24] Presiden Republik Indonesia, Peraturan Pemerintah Republik Indonesia No. 74 Tahun 2008 tentang Guru. 2008.
[25] Menteri Pendidikan Nasional Republik Indonesia, Peraturan Menteri Pendidikan Nasional Republik Indonesia No. 27 Tahun 2008 tentang Kualifikasi dan Kompetensi Konselor. 2008.

[26] J. C. Ball and A. Ross, The effectiveness of methadone maintenance treatment: patients, programs, services, and outcome. Springer Science \& Business Media, 2012.

[27] J. A. Lewis, T. R. Packard, and M. D. Lewis, Management of human service programs. Cengage Learning, 2011.

[28] V. Yuca, Daharnis, and R. Ahmad, "Hubungan Dukungan Sosial Kepala Sekolah dan Kecukupan Sarana Prasarana dengan Pelaksanaan Layanan Bimbingan dan Konseling di Sekolah,” 2015.

[29] M. Y. Gagarin, "Pengaruh Sarana dan Prasarana Sekolah terhadap Kinerja Guru di Kabupaten Alor Nusa Tenggara Timur," 2010.

[30] E. Djatmiko, "Pengaruh Kepemimpinan Kepala Sekolah dan Sarana Prasarana terhadap Kinerja Guru SMP Negeri Kota Semarang," 2006.

[31] C. Radford, A. Prince, K. Lewis, and T. Pal, "Factors which impact the delivery of genetic risk assessment services focused on inherited cancer genomics: expanding the role and reach of certified genetics professionals," J. Genet. Couns., vol. 23, no. 4, pp. 522-530, 2014.

[32] A. L. Albright and E. W. Gregg, "Preventing type 2 diabetes in communities across the US: the National Diabetes Prevention Program," Am. J. Prev. Med., vol. 44, no. 4, pp. S346S351, 2013.

[33] Presiden Republik Indonesia, Peraturan Pemerintah Republik Indonesia No. 19 Tahun 2005 tentang Standar Nasional Pendidikan. 2005.

[34] Menteri Pendidikan Nasional Republik Indonesia, Peraturan Menteri Pendidikan Nasional Republik Indonesia No. 24 Tahun 2007 tentang Standar Sarana dan Prasarana. 2007.

[35] M. G. Lodico, D. T. Spaulding, and K. H. Voegtle, Methods in educational research: From theory to practice, vol. 28. John Wiley \& Sons, 2010.

[36] C. A. Mertler and R. V. Reinhart, Advanced and multivariate statistical methods: Practical 
application and interpretation. Routledge, 2016.

[37] D. C. Ray, "Single $\square$ Case Research Design and Analysis: Counseling Applications," J. Couns. Dev., vol. 93, no. 4, pp. 394-402, 2015.

[38] K. Singh, Quantitative Social Research Methods. Singapore: Sage Publications AsiaPasific, 2007.

[39] I. Melita, "Pengaruh Kemampuan Kognitif Guru, Supervisi, dan Sarana Prasarana terhadap Kinerja Guru SMA Negeri 11 Padang," 2008.

[40] J. B. Miller, Principles of public and private infrastructure delivery, vol. 101. Springer Science \& Business Media, 2013.

[41] J. N. Eichmeyer, C. Burnham, P. Sproat, R. Tivis, and T. M. Beck, "The value of a genetic counselor: improving identification of cancer genetic counseling patients with chart review," J. Genet. Couns., vol. 23, no. 3, pp. 323-329, 2014. 